\title{
Methods for recovering natural values of degraded agricultural areas
}

\section{Metody przywracania walorów przyrodniczych zdegradowanym obszarom rolniczym}

\author{
Jolanta Kowalska*, Joanna Łukaszyk
}

\section{Summary}

The paper discusses soil recovering and remediation methods. It describes process for carrying heavy metals (HM) into forms inaccessible to plants, with particular emphasis on the method of stabilising chemical forms of HM in soil, methods of partial removal of HM from soil (phytoremediation, phytodegradation and bioremediation) and land usage change. It points out the benefits of using nanotechnology in environmental protection and the possibility of using hybrid nanocompounds to solidify heavy metals regardless of soil pH. Soil liming is the cheapest effective and commonly used method for immobilising heavy metals. In the case of phytoremediation, the negative factor is its very long duration and the problem of utilisation of contaminated biomass.

Key words: DDT, hemp, consortium of microorganisms, energy crops, recultivation and remediation techniques

\section{Streszczenie}

W pracy omówiono procesy rekultywacji i remediacji gleb, opisano metody przeprowadzenia metali ciężkich (MC) w formy niedostępne dla roślin, ze szczególnym uwzględnieniem metody stabilizacji form chemicznych MC w glebie, metody częściowego usunięcia MC z gleby (fitoremediację, fitodegradację i bioremediację) oraz zmiany użytkowania gruntów. Wskazano korzyści z wykorzystania nanotechnologii w ochronie środowiska oraz możliwość zastosowania hybrydowych nanozwiązków do solidyfikacji metali ciężkich niezależnie od pH gleby. Najtańszą, skuteczną i powszechnie stosowaną metodą powodującą unieruchomienie metali ciężkich jest wapnowanie gleb. W przypadku fitoremediacji negatywnym czynnikiem jest bardzo długi czas jej trwania oraz problem utylizacji powstałej zanieczyszczonej biomasy.

Słowa kluczowe: DDT, konopie, konsorcjum mikroorganizmów, rośliny energetyczne, techniki rekultywacyjne i remediacyjne

Instytut Ochrony Roślin - Państwowy Instytut Badawczy

Zakład Metod Biologicznych i Rolnictwa Ekologicznego

Władysława Węgorka 20, 60-318 Poznań

*corresponding author: j.kowalska@iorpib.poznan.pl

ORCID: 0000-0002-0588-7355 


\section{Wstęp / Introduction}

Związki chemiczne, pierwiastki promieniotwórcze oraz mikroorganizmy występujące $\mathrm{w}$ nadmiernych ilościach są przyczyną zanieczyszczeń gleby. Pochodzą one z odpadów przemysłowych i komunalnych, emisji przemysłowych, spalin oraz nawozów sztucznych i środków ochrony roślin. Przyczyniają się one do zmian właściwości gleby i negatywnie wpływają na rozwój roślin i ich plony. Wyodrębnia się cztery stopnie degradacji gleby: degradację lekką, umiarkowaną, silną oraz degradację ekstremalną, gdy gleba jest całkowicie zdegradowana i całkowicie utraciła naturalne funkcje biologiczne i odporność na zanieczyszczenia. Niebezpieczeństwo wiążące się z obecnością zanieczyszczeń w glebie jest związane z ich przemieszczaniem się do wód i ich zanieczyszczaniem (Zadroga i Olańczuk-Neyman 2001).

Niniejszy artykuł ma charakter pracy przeglądowej i omawia aspekty związane $z$ chemicznym zanieczyszczeniem gleb oraz z metodami przywracania ich użyteczności środowiskowej i/lub rolniczej. Opracowano wiele technik rekultywacji gleby dla gleb zanieczyszczonych metalami ciężkimi, niestety niektóre $\mathrm{z}$ nich nie są wydajne ze względu na konieczny czas ich trwania, koszty i wpływ na środowisko (Dermont i wsp. 2008). Technologie rekultywacji gleby są czasochłonne i kosztowne, dlatego konieczne było opracowanie technik, które mogą przetwarzać i stabilizować metale ciężkie in situ w wydajny i opłacalny sposób.

\section{Przyczyny degradacji gleb / Reasons of soil degradation}

Przemysł jest jedną z głównych przyczyn degradacji terenu, głównie z powodu depozytowania metali ciężkich (MC) zawartych w emisjach pyłowych (Kabata-Pendias i Pendias 1993; Ross 1994; Wolt 1994). Mówiąc o degradacji gleby w następstwie działalności przemysłowej, agrotechnicznej lub innej, należy mieć na uwadze niekorzystne zmiany zarówno tworu geologicznego, jak również rzeźby terenu, warunków wodnych, czy szaty roślinnej (Siuta 1998). Zanieczyszczenia gleb są ściśle powiązane między innymi z rozwijającym się przemysłem, postępującą urbanizacją, rolnictwem i górnictwem. Uwzględniając znaczną rozpuszczalność związków metali ciężkich (np. Pb, Zn), mogą one stwarzać zagrożenie dla wierzchniej warstwy gleby oraz dla wód powierzchniowych i podziemnych, które często są źródłem wody pitnej (Järup 2003; Sollitto i wsp. 2010; Rozpondek i Wancisiewicz 2016).

Najbardziej niebezpieczna pod względem ekologicznym jest podwyższona koncentracja metali ciężkich w warstwie ornej gleby, ponieważ istnieje niebezpieczeństwo wniknięcia metali przez system korzeniowy i dostania się ich do części jadalnych roślin. Zjawisko to stwarza zagrożenie dla zdrowia ludzi i zwierząt, przyczynia się również do produk- cji żywności niższej jakości (Rosada 2008). Występujące w glebach metale pojawiają się w formach rozpuszczalnych i wymiennych. Dostępność tych szkodliwych zanieczyszczeń w znacznym stopniu zależy od intensywności zachodzących w glebie procesów adsorpcji i desorpcji. Sorpcyjne właściwości gleb są ściśle powiązane z ich zdolnościami buforowymi, wynikającymi ze stabilizowania odczynu glebowego oraz odporności na wpływ zanieczyszczeń chemicznych (Siebielec i wsp. 2008; Kwiatkowska-Malina i Maciejewska 2011). Gleby zanieczyszczone MC muszą być odpowiednio wykorzystywane rolniczo. Obszary charakteryzujące się bardzo silnym zanieczyszczeniem powinny być poddane zmianie formy ich użytkowania, takie obszary kwalifikują się do przeprowadzenia procesu rekultywacji lub remediacji (Maciejewska 2003; Rosada 2008).

\section{Rekultywacja i remediacja / Recovering and remediation}

Rekultywacja polega na przywróceniu stanu odpowiadającego obowiązującym standardom jakości, przy czym standard jakości określa zawartość niektórych substancji w glebie, poniżej których żadna z funkcji pełnionych przez glebę nie jest naruszona. Proces przywracania obszarom zdegradowanym lub zdewastowanym właściwości użytkowych, bądź też przyrodniczych kończy się w momencie osiągnięcia przez glebę lub podłoże odpowiedniej zawartości substancji zgodnych z ściśle określonymi normami (Anonim 2004). Rekultywacja obszarów zdegradowanych jest bardzo istotnym zagadnieniem ze względu na fakt, jakim jest ograniczoność i wyczerpywalność zasobu jakim jest przestrzeń. Stanowi ona również nierozerwalny składnik procesu zmiany sposobu zagospodarowania danego rejonu (Gasidło 1998). Podjęcie działań związanych z rekultywacją związane jest z zakończeniem wcześniejszej działalności. Następujące po rekultywacji zagospodarowanie, rozpoczyna odmienny sposób użytkowania terenu. Prawidłowe przeprowadzenie nowego zagospodarowania terenu odgrywa bardzo ważną rolę dla stanu środowiska i funkcjonującej w nim społeczności (Malewski 1999; Kubicka 2014).

Działania rekultywacyjne przeprowadzane są w trzech etapach, na które składają się: faza przygotowawcza (dokumentacyjna), techniczna (podstawowa) oraz biologiczna (szczegółowa) (Radwańska i wsp. 2016).

Remediacja to poddanie gleby, ziemi i wód gruntowych działaniom mającym na celu usunięcie lub zmniejszenie ilości substancji powodujących ryzyko, ich kontrolowanie oraz ograniczenie rozprzestrzeniania się pod kątem ograniczenia zagrożenia dla zdrowia ludzi i środowiska z uwzględnieniem planowanego sposobu użytkowania terenu. Remediacja może również przebiegać na zasadzie samooczyszczania, pod warunkiem że przynosi korzyści dla środowiska (Anonim 2014). 


\section{Techniki rekultywacji / Remediation techniques}

W odniesieniu do efektu rolnośrodowiskowego podaje się najczęściej stosowane trzy techniki rekultywacji: przeprowadzenie metali ciężkich $\mathrm{w}$ formy niedostępne dla roślin, częściowe usunięcie metali ciężkich z gleby, zmiany form użytkowania gruntów (rys. 1).
W pracy Hseu i wsp. (2010) wymieniono również inne metody rekultywacji, takie jak: przemieszanie gleby i rozcieńczenie zanieczyszczenia, stabilizacja zanieczyszczeń in situ poprzez zmiany chemiczne i fitoremediacja w terenie. Pierwsza z podanych przez Hseu i wsp. (2010) technik jest alternatywną technologią przywracania gleby zanieczyszczonej metalami ciężkimi do ich pierwotnej funkcji

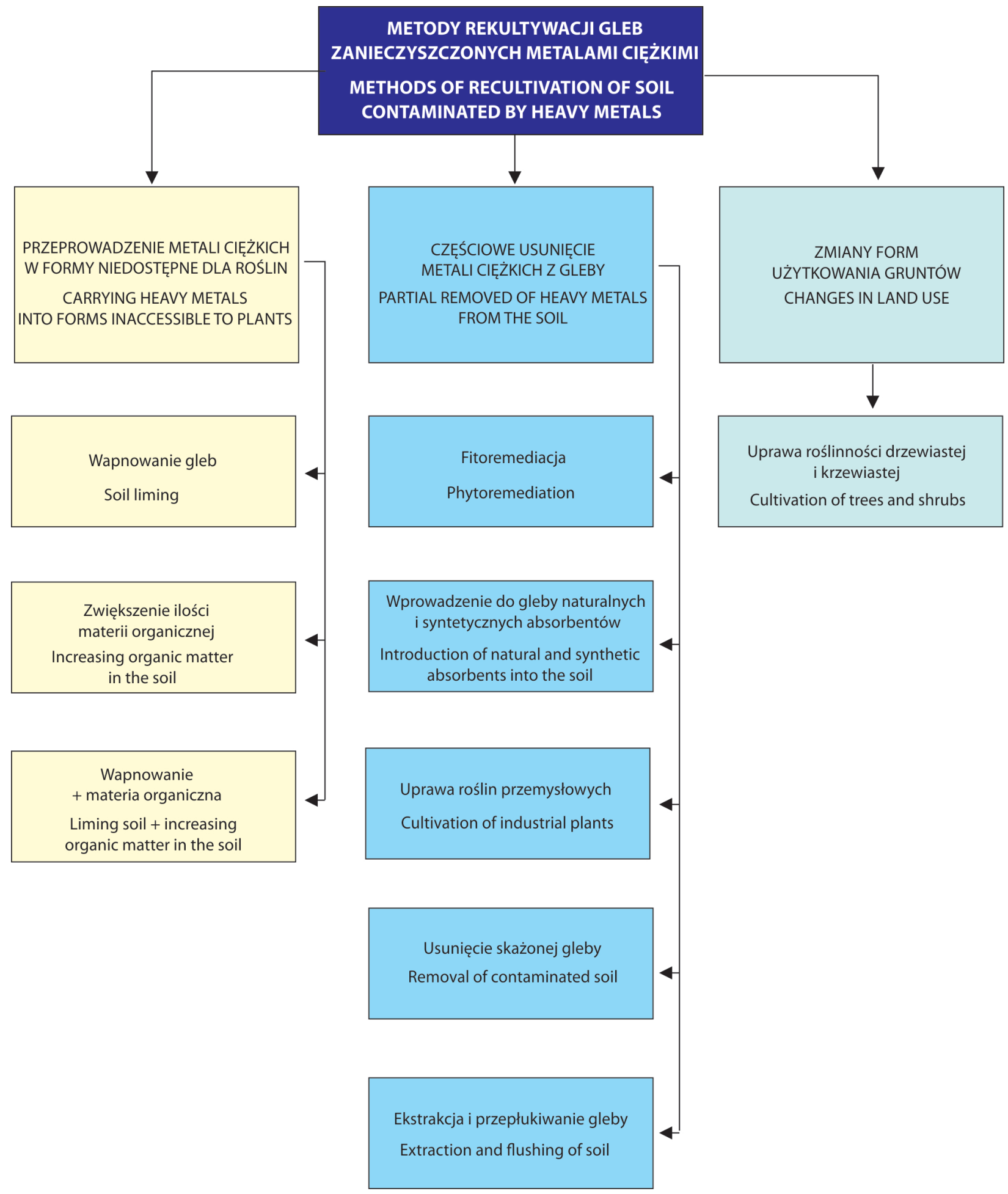

Rys. 1. Metody rekultywacji gleb zanieczyszczonych metalami ciężkimi (Maciejewska 2003)

Fig. 1. Methods for recovering of soils contaminated with heavy metals (Maciejewska 2003) 
$\mathrm{w}$ rolnictwie. Ta metoda polega na wymieszaniu zanieczyszczonej gleby powierzchniowej $(0-30 \mathrm{~cm})$ z czystą glebą podpowierzchniową $(30-100 \mathrm{~cm})$ in situ przy użyciu narzędzi mechanicznych w celu zmniejszenia stężenia metali ciężkich w glebie na głębokości $1 \mathrm{~m}$. Zaletą tej metody jest niski koszt i czas - następuje szybkie obniżenie całkowitego stężenia metali ciężkich. Metoda ta jednak przyczynia się do obniżenia zawartości węgla organicznego i innych składników odżywczych w warstwach ornych gleb. W związku z tym, oczyszczoną glebę należy nawieźć kompostem i nawozem mineralnym, aby odzyskać jej żyzność. Chen i Lee (1997) zastosowali tę metodę w celu zmniejszenia stężenia kadmu $(\mathrm{Cd})$ i ołowiu $(\mathrm{Pb})$. Glebę z warstwy wierzchniej $(0-20 \mathrm{~cm})$ zmieszano z warstwą głębszą $(20-40 \mathrm{~cm})$, a następnie wysadzono sałatę, seler i kapustę chińską. Rekultywacja gleb bardzo silnie skażonych MC poprzez całkowite usunięcie warstwy próchniczno-ornej i ewentualne jej wymieszanie $\mathrm{z}$ glebą niezanieczyszczoną w proporcjach gwarantujących obniżenie poziomu MC poniżej wymaganego jest kosztowna i metoda ta może być stosowana tylko w przypadku likwidowania skażeń punktowych. Natomiast niemożliwe jest przeprowadzenie tą metodą rekultywacji dużych obszarów gruntów rolnych skażonych metalami ciężkimi.

Kolejna metoda dotyczy stabilizacji form chemicznych metali ciężkich występujących w glebie. Emisje kwaśne wywołują zakwaszenie środowiska naturalnego i cały szereg skutków ubocznych, w tym szczególnie niebezpieczny wzrost mobilności metali ciężkich w glebie. Problem skażenia środowiska tymi zanieczyszczeniami zaliczany jest do tradycyjnych problemów ekologicznych o rosnącym znaczeniu. Każdy organizm posiada indywidualną zdolność selektywnego przyswajania MC. Zjawisko to może przebiegać różnie na różnych etapach rozwoju roślin i zwierząt, niezależnie od wielkości stężenia danego metalu $\mathrm{w}$ ekosystemie. Istotne znaczenie w procesie przyswajania metali ciężkich ma efekt synergiczny. Stabilizowanie form chemicznych metali ciężkich w glebie polega na zapobieganiu wzrostowi zakwaszenia gleby związkami alkalizującymi. Na dużych obszarach powszechnie stosuje się metodę stabilizacji chemicznej MC za pomocą wapnowania. Jest ona skuteczna, jednak bardzo zależna od pH gleby, zmieniającego się wraz ze wzrostem czasu trwania tzw. opadu kwaśnego. Ze wzrostem zakwaszenia środowiska rolniczego wzrasta mobilność glebowa MC i ich przyswajalność przez rośliny. Zaletą tej metody jest możliwość skutecznego stosowania na dużych obszarach w warunkach in situ. Wadą natomiast konieczność systematycznego uwzględniania zmian pH gleby wywołanego nie tylko emisją lokalną, ale także transgraniczną, co jest bardzo trudne ze względu na wpływ wielu zmiennych. Dlatego jej stosowanie oznacza konieczność podjęcia działań interdyscyplinarnych w zakresie technologii, ekologii i inżynierii środowiskowej. Dopiero taka współpraca daje możliwość przywracania ob- szarów objętych emisjami przemysłowymi do bezpiecznego wykorzystania ich w produkcji żywności. Metoda ta jest obecnie powszechnie stosowana na obszarach obecnych lub byłych stref ochronnych zakładów przemysłowych (Grzesiak 2019). Przeprowadzenie MC w formy niedostępne dla roślin, bądź przez stabilizację form chemicznych w których występują, zwiększenie ilości materii organicznej lub zastosowanie tych technik jednocześnie jest kolejną metodą. Te metody rekultywacji pozwalają przeprowadzić MC w formę silnych kompleksów chelatowych oraz innych połączeń, dzięki czemu MC są trudno dostępne dla roślin. Proces ten prowadzi do unieruchomienia i dezaktywacji metali występujących w podłożu w wyniku powstania kompleksów, czego efektem jest utrudnienie ich przenikania do łańcucha troficznego ekosystemu. Dzięki takim działaniom minimalizujemy powstawanie negatywnych dla zdrowia człowieka skutków zdrowotnych i ekologicznych (Karczewska 2002; Maciejewska 2003). Nawożenie gleb nawozami organicznymi i ich systematyczne wapnowanie powoduje znaczącą poprawę ich właściwości sorpcyjnych.

Stabilizacja in situ poprzez odpowiednie zabiegi chemiczne jest jedną z najbardziej opłacalnych technik rekultywacji gleby w miejscach zanieczyszczonych metalami ciężkimi (Chen i wsp. 2004). Sorpcja, wymiana jonowa i wytrącanie to podstawowe mechanizmy stosowane do przekształcania rozpuszczalnych i wcześniej istniejących potencjalnie rozpuszczalnych form fazy stałej metali ciężkich w bardziej stabilne biogeochemicznie fazy stałe, tym samym zmniejszając pulę metali ciężkich pobieranych przez korzenie. Do gleby wprowadza się naturalne lub sztuczne dodatki, takie jak wapno, fosforan, zeolit, bentonit, glinę, uwodnione tlenki żelaza i mangan oraz materię organiczną (Cheng i wsp. 2009)

\section{Wykorzystanie hybrydowych nanozwiązków / The use of hybrid nanocompounds}

Bardzo wysokie oczekiwania związane są z wykorzystaniem nanotechnologii w ochronie środowiska i ochronie roślin, jako nowoczesnych metod przyszłościowych. Znane są metody modyfikowania powierzchni różnych matryc grupami funkcyjnymi. Grupy funkcyjne czynne są odpowiedzialne za wiązanie MC, natomiast grupy bierne stanowią dystans molekularny umożliwiający przyłączenie kationów o odpowiednim promieniu jonowym. Opracowana jest unikalna metoda trwałego wiązania MC w glebie (solidyfikacja) za pomocą hybrydowych nanozwiązków niezależnie od pH gleby. Hybrydowe materiały z selektywnymi receptorami molekularnymi znajdują szerokie zastosowanie. $Z$ punktu widzenia zastosowania tego typu materiałów istotny jest charakter wiązania chemicznego pomiędzy fragmentem nieorganicznym a organicznym (receptorem molekularnym). Jej zastosowanie w istotny sposób zwiększy 
bezpieczeństwo żywności, w tym szczególnie na obszarach o specyficznych warunkach uprawy. Wdrażanie tej metody wymaga opracowania instrukcji stosowania dedykowanych układów hybrydowych z uwzględnieniem skutków tego mechanizmu w uprawach roślinnych. Zastosowanie solidyfikacji będzie miało olbrzymie znaczenie praktyczne i w sposób istotny poprawi bezpieczeństwo środowiska. Wdrożenie tej metody może zrewolucjonizować współczesne rolnictwo (Grzesiak i wsp. 2016; Grzesiak 2019).

Poddawane działaniom rekultywacyjnym gleby wyrobisk, składowisk odpadów górniczych, energetycznych i przemysłowych, a także gleby terenów poprzemysłowych charakteryzują się zazwyczaj wadliwym uziarnieniem, brakiem prawidłowej struktury, niewłaściwymi stosunkami powietrzno-wodnymi oraz niedostatkiem próchnicy i składników pokarmowych dla roślin. W celu przeprowadzenia efektywnej rekultywacji biologicznej trzeba równocześnie poprawić właściwości fizykochemiczne gleby i jej nawożenie. Warunek ten można zrealizować poprzez zastosowanie nawozów organicznych (Klimont 2007; Karczewska 2008).

Stosunkowo nowym zagadnieniem jest badanie wpływu prądu elektrycznego na właściwości fizykochemiczne gleb. Prąd elektryczny może przyczyniać się do zmiany pH gleby i przewodności elektrycznej. Obrazem tego procesu będzie rozmieszczenie potencjału elektrycznego w próbce gleby. Proces ten posłuży do opracowania technologii fitoremediacji opartej na wykorzystaniu prądu. W wyniku przeprowadzonych badań stwierdzono, że niskie lub umiarkowane gradienty napięcia $(0,67 \mathrm{~V} / \mathrm{cm})$ wywołały niewielkie zmiany właściwości fizykochemicznych gleby. Zmiany te nie stanowią zagrożenia dla roślin. Zastosowany w badaniach gradient napięcia przeprowadzono $w$ testach na glebach zanieczyszczonych metalami ciężkimi $(\mathrm{Cd}, \mathrm{Co}, \mathrm{Cr}, \mathrm{Cu}$, $\mathrm{Pb}$ i $\mathrm{Zn}$ ). Do badań wytypowano dwa gatunki roślin, które były przystosowane do panujących warunków glebowych i klimatycznych (Brassica rapa L. subsp. rapa i Lolium perenne L.). Pole elektryczne przyczyniło się do zwiększenia plonu roślin (głównie u L. perenne) i zwiększyło fitoremediację oraz wchłanianie metali ciężkich. W wyniku przeprowadzonych analiz stwierdzono, że mieszane uprawy obu gatunków roślin są obiecujące i można je stosować na dużą skalę (Cameselle i wsp. 2019).

\section{Metody biologiczne / Biological methods}

Jedną z kolejnych technik jest fitoremediacja przydatna do oczyszczania gleb zanieczyszczonych przez metale ciężkie w stopniu niskim lub średnim (Lai i Chen 2005). Jednak większość gatunków roślin hiperakumulacyjnych używanych do „usuwania” metali ciężkich ma słaby przyrost biomasy pędu i powolny wzrost. Przykładowe gatunki roślin hiperakumulacyjnych to Thlaspi alpestre, Arabidopsis halleri, Armeria maritima ssp. halleri (Brej i Fabiszewski 2006). Możliwe jest zastosowanie dodatkowych substancji w celu zwiększenia biodostępności metali, a także zwiększenia ilości metali ciężkich pobieranych przez rośliny. Wykorzystanie EDDS (kwas etylenodiaminodibursztynowy), HEDTA (kwas hydroksyetyloetylenodiaminotetraoctowy), EDTA lub NTA (nitrylotrioctan) znacznie podnosi stężenie metali ciężkich w pędach roślin (Meers i wsp. 2005). Transport jonów $\mathrm{Cd}$ i $\mathrm{Pb}$ z korzenia do pędu (współczynnik translokacji - TF) wzrasta podczas stosowania EDTA (Chen i wsp. 2004). Zazwyczaj to korzenie roślin gromadzą wyższe stężenia metali ciężkich niż pędy. Wydłużenie wegetacji i wzrostu roślin z 1 miesiąca do 2 miesięcy sprzyja akumulacji metali ciężkich w korzeniach, nie znajduje to jednak potwierdzenia w przypadku cynku. Fitoremediacja dotyczy wykorzystania roślin do usuwania, przenoszenia, stabilizacji oraz degradacji zanieczyszczeń, które występują w glebach lub osadach. Proces ten zachodzi w rizosferze, a substancje wydzielane w sposób naturalny przez korzenie zapewniają mikroorganizmom odpowiednią ilość składników odżywczych powodujących intensyfikację procesów biologicznych. Ponadto obumarłe fragmenty korzeni powodują kształtowanie się kanałów do transportu wody i powietrza, które są konieczne do rozwoju mikroorganizmów (Zaleska i Zielińska-Jurek 2013).

W procesiefitoremediacji występują cztery mechanizmy usuwania zanieczyszczeń: fitoekstrakcja, fitostabilizacja, fitodegradacja i bioremediacja.

\section{Fitoekstrakcja / Fitoextraction}

Fitoekstrakcja polega na wykorzystaniu zdolności niektórych roślin do zatrzymywania zanieczyszczeń w nadziemnych częściach roślin (Żurek i Majtkowski 2009; Olszak 2015). Zaliczana jest do technik znajdujących najczęstsze zastosowanie do oczyszczania gleb i osadów, które są skażone substancjami nieorganicznymi, zwłaszcza metalami ciężkimi i substancjami radioaktywnymi. Roślina pobiera je, a później transportuje do poszczególnych tkanek, w których są one koncentrowane i zakumulowane. W celu zwiększenia pobieranych ilości poszczególnych MC, do gleby dodaje się związki chelatujące. Ostatnio brane są pod uwagę rośliny modyfikowane genetycznie. W licznych laboratoriach przeprowadzane są badania nad uzyskaniem transgenicznych roślin skutecznych w fitoremediacji. Rośliny takie miałyby zdolność pobierania i metabolizowania wysokich ilości związków toksycznych ze środowiska np. otrzymane transgeniczne okazy Nicotiana glauca z genem TaPCS1 kodującym syntezę fitochelatynową, wykazały wzrost akumulacji i tolerancji na Pb i Cd (Siwek 2008). 


\section{Fitostabilizacja / Fitostabilization}

Fitostabilizacja polega na wykorzystaniu zdolności roślin do zmiany właściwości zanieczyszczeń, dzięki czemu stają się one unieruchomione w glebie. Dzięki temu procesowi metale ciężkie pozostają związane w podłożu glebowym. Oddziaływanie roślin na występujące w podłożu metale ciężkie wynika z ich oddziaływania na środowisko glebowe oraz chemizm zanieczyszczeń. Produkowane przez rośliny związki organiczne uwalniane do rizosfery oraz dwutlenek węgla mogą zmieniać pH gleby, wpływać na jej potencjał oksydoredukcyjny oraz redukować jony toksycznych metali do form niedostępnych dla roślin. Unieruchomione w wyniku tego procesu substancje posiadają ograniczoną zdolność do przemieszczania się w głąb profilu glebowego, do wód gruntowych oraz do dalszych ogniw łańcucha pokarmowego (Siwek 2008).

\section{Fitodegradacja / Fitodegradation}

Fitodegradacja (fitotransformacja) polega na wykorzystaniu zdolności poszczególnych gatunków roślin do pobierania zanieczyszczeń ze skażonych miejsc, a w kolejnym etapie ich transformacji przy pomocy kompleksów enzymatycznych cyklu metabolicznego. Fitodegradacja może również przebiegać na zewnątrz roślin w strefie korzeniowej. Zachodzi to dzięki enzymom degradującym wydzielanym do środowiska. Istotną rolę $\mathrm{w}$ procesie degradacji ksenobiotyków odgrywają także interakcje pomiędzy korzeniami roślin a mikroorganizmami ich rizosfery. Metoda fitodegradacji stosowana jest do likwidacji różnych zanieczyszczeń organicznych z gleby, osadów, a także wód gruntowych i powierzchniowych. Do tej grupy zaliczyć można rośliny, których płody wykorzystuje się do wytwarzania ciepła, energii elektrycznej albo paliw ciekłych lub gazowych np. miskant, ślazowiec, słoma zbóż, topinambur, buraki cukrowe, rzepak, słonecznik, len (Siwek 2008).

\section{Bioremediacja / Bioremediation}

Polega na oczyszczaniu gleby z MC, substancji radioaktywnych oraz związków organicznych za pomocą bakterii, grzybów, glonów oraz roślin (Malik 2004). Mikroorganizmy charakteryzują się właściwościami, które umożliwiają przeprowadzenie biodegradacji związków organicznych oraz detoksyfikacji toksycznych form metali na mniej toksyczne, które występują w formach niedostępnych dla roślin ( $\mathrm{Se}, \mathrm{Cr}, \mathrm{Fe}, \mathrm{Mn}$ ). Potrafią też wydzielać na zewnątrz związki wiążące i unieczynniające metale. Mikroorganizmy posiadają również zdolność do przeprowadzenia zamiany form jonowych metali na lotne formy nietoksyczne w procesie wolatylizacji, np. jonów $\mathrm{Hg}(\mathrm{II})$ na $\mathrm{Hg}(0)$ (Garbisu i Alkorta 2001). Metale ciężkie nie mogą być rozkładane biologicznie, dlatego też mikroorganizmy wpływają na zmianę ich rozpuszczalności powodując tym samym zmniejszenie ich toksyczności (Dzionek i wsp. 2016). Mikroorganizmy mające zdolności degradujące zanieczyszczenia występujące w glebach stanowią około $10 \%$ całkowitej populacji, w związku z tym oczyszczanie środowiska przy ich zastosowaniu trwa bardzo długo. $\mathrm{Na}$ proces bioremediacji in situ składają się trzy metody, które przeprowadza się z wykorzystaniem mikroorganizmów: naturalna bioremediacja (monitorowaie zanieczyszczeń bez ingerencji człowieka), biostymulacja (stosuje się ją w sytuacjach, gdy tempo naturalnego procesu rozkładu ksenobiotyków jest niewystarczające, w celu przyspieszenia przebiegu oczyszczania) oraz bioaugmentacja (powiększenie puli mikroorganizmów w wyniku wprowadzania do zanieczyszczonego miejsca pojedynczych szczepów lub konsorcjów mikrobiologicznych, które są wyspecjalizowane w usuwaniu zanieczyszczeń). Metody biologiczne stosowane do przywracania środowiska do stanu właściwego, w literaturze naukowej opisywane są jako tańsze oraz bardziej skuteczne od metody fizykochemicznych. Ponadto bioremediacja jest neutralna $\mathrm{w}$ kontekście bezpieczeństwa środowiskowego (Warczewska i wsp. 2018).

$\mathrm{Na}$ całym świecie stosowano DDT jako insektycyd do zwalczania szkodników rolniczych i wektorów chorób, które były przenoszone przez owady. W wielu krajach środek ten został zakazany, lecz ze względu na jego trwałość jest on nadal obecny w środowisku i stanowi długoterminowe zagrożenie. Postanowiono więc do celów bioremediacji terenów skażonych DDT wybrać odpowiednie gatunki grzybów (badano szczepy Trichoderma hamatum FBL 587 i Rhizopus arrhizus FBL 578). Wybrane szczepy badano pod kątem wszechstronności katabolicznej na 95 źródłach węgla z DDT lub bez, stosując przy tym system fenotypowy MicroArray, aby zbadać indukowane odpowiedzi na stres oksydacyjny. Oba szczepy były zdolne do wykorzystania większości dostarczonych substratów. Skutkiem tych reakcji była wysoka wszechstronność metaboliczna i funkcjonalność ekologiczna w stosowaniu źródeł węgla pomimo obecności DDT (Russo i wsp. 2019). Pozostałości DDT wykryto w około $80 \%$ próbek gleby pobranych z różnych miejsc znajdujących się w 8 województwach w całym kraju. Jednak tylko $25 \%$ roślin uprawianych na zanieczyszczonych glebach zawierało pozostałości DDT i tylko w tkankach korzeni. Zaszczepienie gleby konsorcjami mikrobiologicznymi (grzyby mykoryzowe, bakterie, drożdże, EM) sprzyjało pobieraniu DDT przez rośliny Cucurbita pepo i magazynowaniu tych pozostałości w częściach nadziemnych roślin. Opracowana strategia rizomediacji wydaje się wspomagać pobieranie i akumulację pozostałości DDT przez rośliny (Tartanus i wsp. 2017). 


\section{Zmiany form użytkowania gruntów / Changes in land use forms}

Ostatnia grupa metod rekultywacji gleb polega na dokonaniu zmiany użytkowania gruntów, które wprowadza się przez zastosowanie nowych nasadzeń roślinnością drzewiastą i krzewiastą. Stosuje się ją najczęściej w przypadku obszarów silnie zanieczyszczonych MC, które nie mogą zostać wykorzystane do produkcji żywności. Na glebach silnie zanieczyszczonych zaleca się uprawę roślin niekonsumpcyjnych. Tereny charakteryzujące się silnym zanieczyszczeniem MC powinny być przeznaczone na cele upraw roślin przemysłowych (np. len, konopie, wiklina) i energetycznych (np. wierzba krzewiasta, ślazowiec pensylwański, miskant). Obszary te można również przeznaczyć pod uprawy ziemniaków dla przemysłu spirytusowego (na spirytus jako dodatek do paliwa) lub rzepaku, który może być przeznaczony do produkcji oleju technicznego (Kabata-Pendias i Pendias 1993). Rośliny energetyczne są przydatne w biologicznej fazie rekultywacji terenów zdegradowanych. Zazwyczaj są to rośliny pionierskie, które rozpoczynają procesy glebotwórcze i powstrzymują wypłukiwanie składników z gleby do wód gruntowych. Dzięki tym walorom, rośliny te mogą być wykorzystane przy uprawie gleb mało urodzajnych lub skażonych oraz do utylizacji osadów ściekowych. Stwarza to możliwość wdrażania alternatywnej produkcji rolnej na terenach zdegradowanych i niskoprodukcyjnych (Radwańska i wsp. 2016). Rośliny energetyczne uprawia się głównie na cele opałowe. $\mathrm{W}$ wyniku intensywnego pobierania $\mathrm{MC}$ $\mathrm{z}$ gleby oraz ich akumulacji w biomasie roślin energetycznych powstają problemy zarówno techniczne, jak i środowiskowe. Produkty uboczne powstające w wyniku procesu spalania lub przy innej formie przerobu biomasy roślin hiperakumulatorów (popioły lub szlamy) mogą charakteryzować się wysokim stężeniem MC. Fakt ten sprawia, że zostają one zakwalifikowane do grupy odpadów niebezpiecznych dla środowiska. Powinny one zostać przetransportowane do zakładów przerabiających rudy metali jako produkt określany jako tzw. biorudy (ang. bioore) w celu wyeliminowania składowania tych odpadów na zwykłych składowiskach popiołów energetycznych (Ghosh i Singh 2005). Problem ten poniekąd można rozwiązać poprzez tzw. współspalanie biomasy roślin z węglem kamiennym. Dzięki temu zabiegowi uzyskuje się obniżenie koncentracji metali ciężkich w popiele lub żużlu (Rybak 2006). Kolejnym efektem ubocznym i zarazem wadą uprawy wieloletnich roślin energetycznych (np. topoli) na zanieczyszczonych glebach jest kumulowanie dużych ilości MC w biomasie liści, które nie podlegają zbiorowi z drewnem lub słomą. Koncentracja pierwiastków śladowych powstająca w wyniku opadania liści powoduje wtórny wzrost (prawdopodobnie przejściowy) zanieczyszczenia powierzchniowej warstwy gleby (Kabała i wsp. 2008). Do zalet uprawy roślin energetycznych należą niewątpliwie ich zdolności adaptacyjne oraz wysoka wartość opałowa. Dzięki tym walorom rośliny energetyczne z powodzeniem mogą być wykorzystane nie tylko na terenach zanieczyszczonych i zdewastowanych przemysłowo, ale także na glebach niższych klas bonitacyjnych, jak i na wszystkich glebach rolniczych, które w związku z wysokim zanieczyszczeniem zostały wykluczone z upraw roślin o charakterze konsumpcyjnym (Radwańska i wsp. 2016).

Jedną z roślin energetycznych są konopie siewne. Ich uprawę możemy zaliczyć do najszybszych naturalnych metod rekultywacji. Udowodniono, że konopie mogą znacznie przyśpieszyć proces rekultywacji terenów poprzemysłowych. Przeprowadzony eksperyment potwierdził, że konopie zastosowane do rewitalizacji pokopalnianych nieużytków działają najszybciej ze wszystkich roślin dotychczas używanych do tego celu. Dzięki tym roślinom już za kilkanaście lat będzie można zasadzić drzewa, stworzyć miejsca lęgowe dla zwierząt lub będą mogły powstać tereny rekreacyjne. Proponowany model rekultywacji przy zastosowaniu konopi mógłby spowodować szybsze przywrócenie rolniczej użyteczności na obszarach zniszczonych przemysłem wydobywczym na całym świecie. Dobroczynne działanie konopi na zdegradowane przemysłem wydobywczym tereny wynika $\mathrm{z}$ tego, iż roślina ta jest bardzo odporna na trudne warunki i produkuje duże ilości biomasy, która po ścięciu zostaje zaorana. W skład biomasy wchodzą również korzenie, które mają dobroczynny wpływ na glebę. Zaorana biomasa w wyniku rozkładu tworzy wysokiej jakości próchnicę, która stanowi świetną pożywkę dla mikroorganizmów. Ponadto uprawa konopi poprawia strukturę gleby i zapobiega erozji wietrznej. Ze względy na uzyskiwanie dużej masy poprodukcyjnej kumuluje ona znaczne ilości metali ciężkich. Ponadto biomasa może być wykorzystana dla potrzeb przemysłu włókienniczego, celulozowo-papierniczego, chemicznego, czy paliwowo-energetycznego. W efekcie końcowym tereny poprzemysłowe zostają przywrócone na cele rolnicze (źródła internetowe).

Podjęcie decyzji dotyczącej wyboru metody rekultywacji jest uzależnione od kilku aspektów. Przy podejmowaniu decyzji należy wziąć pod uwagę: rodzaj gruntu oraz budowę podłoża glebowego, rodzaj zanieczyszczeń (ich stężenie, właściwości, stan skupienia i ewentualną zdolność biodegradacji), stopień i obszar zanieczyszczenia gruntu, obecność szkodliwych zanieczyszczeń w warstwie ornej gleb oraz ryzyko ich przeniknięcia do wód gruntowych (w tym do wody pitnej). Istotną kwestią jest również decyzja dotycząca sposobu i rodzaju wykorzystania danego obszaru po przeprowadzeniu rekultywacji bądź rewitalizacji danego terenu (Zaleska i Zielińska-Jurek 2013).

\section{Podsumowanie / Resume}

W powyższej pracy omówiono przyczyny degradacji gleb, głównie z powodu zwiększonej zawartości metali ciężkich. Scharakteryzowane zostały też procesy rekultywacji i remediacji gleb. Uzasadniono konieczność ich 
stosowania do zabezpieczania gleb zanieczyszczonych związkami chemicznymi i pierwiastkami promieniotwórczymi oraz mikroorganizmami. Opisano też metody przeprowadzenia MC w formy niedostępne dla roślin, ze szczególnym uwzględnieniem metody stabilizacji form chemicznych MC w glebie, metody częściowego usunięcia MC z gleby (fitoremediację, fitodegradację i bioremediację) oraz zmiany użytkowania gruntów. Wskazano korzyści z wykorzystania nanotechnologii $\mathrm{w}$ ochronie środowiska i roślin jako metod przyszłościowych. Podkreślono możliwość zastosowania hybrydowych nanozwiązków do solidyfikacji metali ciężkich niezależnie od pH gleby. Wszystkie przedstawione techniki mają wady i zalety. W przypadku rekultywacji terenów objętych emisjami przemysłowymi należy pamiętać, że często obejmują one duże obszary (kilka tysięcy hektarów) i należy dobrać właściwe rozwiązania umożliwiające skuteczną metodę przywracania tych gruntów do stanu użyteczności. Najtańszą, skuteczną i powszechnie stosowaną metodą powodującą unieruchomienie MC jest wapnowanie gleb. Ze względu na kosztowność metod stosowanych w rekultywacji należy uwzględnić aspekt ekonomiczny. Wadą tych metod jest problem zagospodarowania powstałych odpadów ubocznych. W przypadku fitoremediacji negatywnym czynnikiem jest bardzo długi czas potrzebny do zakończenia procesu odbudowy objętych nią obszarów. Tak jak w przypadku metod rekultywacji i remediacji, problem stanowi utylizacja powstałej zanieczyszczonej biomasy.

\section{Literatura / References}

Anonim 2004. Program Rządowy dla Terenów Poprzemysłowych. Ministerstwo Środowiska, Warszawa, 27 kwietnia 2004.

Anonim 2014. Remediacja i rekultywacja gruntów rolnych, art. 3, 75 pkt 31b, Prawo Ochrony Środowiska-przepis dodany po nowelizacji z dnia 11 lipca 2014 r. Dz. U., poz. 1101.

Brej T., Fabiszewski J. 2006. Plants accumulating heavy metals in the Sudety MTS. Acta Societatis Botanicorum Poloniae 75 (1): $61-68$.

Cameselle C., Gouveia S., Urréjola S. 2019. Benefits of phytoremediation amended with DC electric field. Application to soils contaminated with heavy metals. Chemosphere 229: 481-488. DOI: 10.1016/j.chemosphere.2019.04.222

Cheng C.H., Jien S.H., Tsai H., Chang Y.H., Chen Y.C., Hseu Z.Y. 2009. Geochemical element differentiation in serpentine soils from the ophiolite complexes, eastern Taiwan. Soil Science 174 (5): 283-291. DOI: 10.1097/SS.0b013e3181a4bf68

Chen Z.S., Lee D.Y. 1997. Evaluation of remediation techniques on two cadmium-polluted soils in Taiwan. s. 209-223. W: Remediation of Soils Contaminated with Metals (I.K. Iskandar, D.C. Adriano, red.). Science Reviews, Northwood, UK.

Chen Y.H., Shen Z.G., Li X.D. 2004. Leaching and uptake of heavy metals by ten different species of plants during an EDTA-assisted phytoextraction process. Chemosphere 57 (3): 187-196. DOI: 10.1016/j.chemosphere.2004.05.044

Dermont G., Bergeron M., Mercier G., Richer-Laflèche M. 2008. Metal-contaminated soils: remediation practices and treatment technologies. Practice Periodical of Hazardous, Toxic, and Radioactive Waste Management 12 (3): 188-209. DOI: 10.1061/ (ASCE) 1090-025X(2008)12:3(188)

Dzionek A., Wojcieszyńska D., Guzik U. 2016. Natural carriers in bioremediation: A review. Electronic Journal of Biotechnology 23: 28-36. DOI: 10.1016/j.ejbt.2016.07.003

Garbisu C., Alkorta I. 2001. Phytoextraction: a cost-effective plant-based technology for the removal of metals from the environment. Biosource Technology 77 (3): 229-236. DOI: 10.1016/s0960-8524(00)00108-5

Gasidło K. 1998. Problemy przekształceń terenów poprzemysłowych. Wydawnictwo Politechniki Śląskiej, Zeszyty Naukowe Politechniki Śląskiej, Architektura 37, 199 ss.

Ghosh M., Singh S.P. 2005. A review of phytoremediation of heavy metals and utilization of it's by products. Asian Journal on Energy and Environment 6 (04): 214-231.

Grzesiak P. 2019. Badania nad technologią i ekologią środowiska. Cursiva, Poznań, 148 ss.

Grzesiak P., Łukaszyk J., Gabała E., Kurczewska J., Schroeder G. 2016. The influence of silica functionalized with silanes on migration of heavy metals in soil. Polish Journal of Chemical Technology 18 (1): 51-57. DOI: 10.1515/pjct-2016-0009

Hseu Z.-Y., Su S.-W., Lai H.-Y., Guo H.-Y., Chen T.-C., Chen Z.-S. 2010. Remediation techniques and heavy metal uptake by different rice varieties in metal-contaminated soils of Taiwan: New aspects for food safety regulation and sustainable agriculture. Soil Science and Plant Nutrition 56 (1): 31-52. DOI: 10.1111/j.1747-0765.2009.00442.x

https://dobrewiadomosci.net.pl/15619-uprawa-konopi-siewnych-najszybsza-naturalna-metoda-rekultywacji-terenow-poprzemyslowych/ [dostęp: 10.04.2020].

https://www.iwnirz.pl/strona,279.html [dostęp: 10.04.2020].

Järup L. 2003. Hazards of heavy metal contamination. British Medical Bulletin 68 (1): 167-182. DOI: 10.1093/bmb/ldg032

Kabała C., Chodak T., Szerszeń L. 2008. Influence of land use pattern on changes in copper content in soils around a copper smelter, based on a 34-year monitoring cycle. Žemès Ukio Mokslai (Agricultural Sciences, Litwa) 15 (3): 8-12.

Kabata-Pendias A., Pendias H. 1993. Biogeochemia pierwiastków śladowych. Państwowe Wydawnictwo Naukowe, Warszawa, 364 ss.

Karczewska A. 2002. Metale ciężkie w glebach zanieczyszczonych emisjami hut miedzi - formy i rozpuszczalność. Zeszyty Naukowe Akademii Rolniczej we Wrocławiu, Rozprawy CLXXXIV, Nr 432, 159 ss.

Karczewska A. 2008. Ochrona gleb i rekultywacja terenów zdegradowanych. Uniwersytet Przyrodniczy we Wrocławiu, 414 ss.

Klimont K. 2007. Ocena przydatności wybranych gatunków roślin użytkowych do rekultywacji terenów zdewastowanych przez przemysł i gospodarkę komunalną. [Evaluating the usability of selected plant species to reclamation of the areas degraded by industry and public utilities]. Problemy Inżynierii Rolniczej 15 (2): 27-36.

Kubicka H. 2014. Planowanie działań rekultywacyjnych w świetle polskich i niemieckich regulacji prawnych (praca magisterska). Politechnika Wrocławska, Wrocław.

Kwiatkowska-Malina J., Maciejewska A. 2011. Pobieranie metali ciężkich przez rośliny w warunkach zróżnicowanego odczynu gleb i zawartości materii organicznej. [The uptake of heavy metals by plants at differentiated soil reaction and content of organic matter]. Ochrona Środowiska i Zasobów Naturalnych 49: 43-51. 
Lai H.-Y., Chen Z.-S. 2005. The EDTA effect on phytoextraction of single and combined metals-contaminated soils using rainbow pink (Dianthus chinensis). Chemosphere 60 (8): 1062-1071. DOI: 10.1016/j.chemosphere.2005.01.020

Maciejewska A. 2003. Problematyka rekultywacji gleb zanieczyszczonych metalami ciężkimi w świetle literatury. s. 539-550. W: Obieg pierwiastków w przyrodzie. Monografia. Tom II (B. Gworek, J. Misiak, red.). Dział Wydawnictw Instytutu Ochrony Środowiska, Warszawa, 730 ss

Malewski J. 1999. Zagospodarowanie wyrobisk. Technologiczne, przyrodnicze i gospodarcze uwarunkowania zagospodarowania wyrobisk poeksploatacyjnych surowców Dolnego Śląska. Oficyna Wydawnicza Politechniki Wrocławskiej, Wrocław, 225 ss.

Malik A. 2004. Metal bioremediation through growing cells. Environment International 30 (2): 261-278. DOI: 10.1016/j. envint.2003.08.001

Meers E., Lamsal S., Vervaeke P., Hopgood M., Lust N., Tack F.M.G. 2005. Availability of heavy metals for uptake by Salix viminalis on a moderately contaminated dredged sediment disposal site. Environmental Pollution 137 (2): 354-364. DOI: 10.1016/j. envpol.2004.12.019

Olszak M. 2015. Fitoremediacja - biologiczna metoda oczyszczania środowiska. Uniwersytet Przyrodniczy w Lublinie. https://www. ebiotechnologia.pl/Artykuly/Fitoremediacja--biologiczna-metoda-oczyszczania-srodowiska/ [dostęp: 10.04.2020].

Radwańska K., Zadrożniak B., Mystkowska I., Baranowska A. 2016. Possibilities of using perennial energy crops in reclamation of degraded land. [Możliwości wykorzystania wieloletnich roślin energetycznych w rekultywacji obszarów zdegradowanych]. Studia Ekonomiczne i Regionalne 9 (4): 70-85.

Rosada J. 2008. Stan środowiska rolniczego w rejonie oddziaływania emisji Huty Miedzi „Głogów”. Rozprawy Naukowe Instytutu Ochrony Roślin - Państwowego Instytutu Badawczego, Zeszyt 19, 110 ss.

Ross S.M. 1994. Toxic metals in soil-plant system. J. Wiley and Sons Ltd., London, 152 ss.

Rozpondek R., Wancisiewicz K. 2016. Analiza rozkładu zanieczyszczeń w osadach dennych z zastosowaniem GIS w przybrzeżnej strefie zbiornika wodnego Ostrowy na rzece Biała Oksza. [Distribution of pollution in sediments in the coastal zone of Ostrowy water reservoir in Biała Oksza river - GIS based approach]. Inżynieria i Ochrona Środowiska 19 (1): 37-49. DOI: 10.17512/ios.2016.1.4

Russo F., Ceci A., Pinzarri F., Sicilliano A., Guida M., Malusa E., Tartanus M., Miszczak A., Maggi O., Persiani A.M. 2019. Bioremediation of dichlorodiphenyltrichloroethane (DDT)-contaminated agricultural soils: potential of two autochthonous saprotrophic fungal strains. Applied Environmental Microbiology 85 (21): 1-61. DOI: 10.1128/AEM.01720-19

Rybak W. 2006. Spalanie i współspalanie biopaliw stałych. Oficyna Wydawnicza Politechniki Wrocławskiej, Wrocław, 411 ss.

Siebielec G., Stuczyński T., Trelak H., Filipiak K., Koza P., Korzeniowska-Pucułek R., Łopatka A., Jadczyszyn J. 2008. Uwarunkowania produkcji rolniczej w regionach o dużym udziale gleb zanieczyszczonych metalami śladowymi. Studia i Raporty IUNG-PIB, Zeszyt 12: $123-143$.

Siuta J. 1998. Rekultywacja gruntów. Poradnik Instytutu Ochrony Środowiska, Warszawa 203 ss.

Siwek M. 2008. Biologiczne sposoby oczyszczania środowiska - fitoremediacja. Wiadomości Botaniczne 52 (1/2): 23-28.

Sollitto D., Romic M., Castrignano A., Romic D., Bakic H. 2010. Assessing heavy metal contamination in soils of the Zagreb region (Northwest Croatia) using multivariate geostatistics. Catena 80 (3): 182-194. DOI: 10.1016/j.catena.2009.11.005

Tartanus M., Malusá R., Łabanowska B., Miszczak A., Szustakowska E. 2017. Ddt content in polish soils - current state and attempts of rhizo-bioremediation. [Zawartość DDT w polskich glebach - stan obecny i próba jego bioremediacji]. Journal of Research and Applications in Agricultural Engineering 62 (4): 178-181.

Waraczewska Z., Niewiadomska A., Grzyb A. 2018. Wybrane metody bioremediacji in situ z wykorzystaniem mikroorganizmów. [Selected methods of bioremediation in situ using microorganisms]. Woda-Środowisko-Obszary Wiejskie 18 (3): 65-78.

Wolt J.D. 1994. Soil solution chemistry. Applications to environmental science and agriculture. J. Wiley and Sons, New York, 360 ss.

Zadroga B., Olańczuk-Neyman K. 2001. Ochrona i rekultywacja podłoża gruntowego. Wydawnictwo Politechniki Gdańskiej, Gdańsk, 228 ss.

Zaleska A., Zielińska-Jurek A. 2013. Technologie remediacji gruntów. Wydawnictwo Politechniki Gdańskiej, Gdańsk, 128 ss.

Żurek G., Majtkowski W. 2009. Rośliny alternatywne w fitoekstrakcji metali ciężkich z obszarów skażonych. [Alternative plant species in phytoremediation of heavy metals from polluted land]. Problemy Inżynierii Rolniczej 17 (3): 83-89. 